\title{
Revue de l'épidémiologie de la maladie de Crohn en Europe
}

\author{
Patricia PIRONT, J. BELAICHE, E. LOUIS
}

Service d'hépatogastroentérologie, Chu Liège (Belgique)

\section{Epidemiology of Crohn's disease in Europe: a review}

\section{RÉSUMÉ}

La maladie de Crohn, une maladie inflammatoire chronique du tube digestif, a une incidence relativement élevée, surtout parmi les sujets jeunes, variant de 0,3 à 9,8 nouveaux cas pour 100000 personnes en Europe.

Les données concernant les variations géographiques, l'incidence au cours des décennies, l'âge de début de la maladie, le délai avant le diagnostic et la localisation de la maladie ont été résumées parmi des travaux effectués en Europe ces dernières années.

\section{SUMMARY}

Crohn's disease, a chronic inflammatory bowel disease of unknown etiology, has a high incidence especially in early adulthood; incidence ranges from 0,3 to 9,8 cases per $10^{5}$ person years in Europe.

Geographic variations, incidence over time, male-female ratio, age at onset, delay before diagnosis, disease location and environmental factors have been studied across Europe over last years.

Mots-clés : épidémiologie; Europe; maladie de Crohn; maladies inflammatoires chroniques intestinales.

Key-words : Crohn's disease; epidemiology; Europe; inflammatory bowel disease.

\section{INTRODUCTION}

La maladie de Crohn (MC) est une maladie inflammatoire chronique qui intéresse tous les niveaux du tractus gastro-intestinal. L'étiologie n'est pas encore connue avec précision mais elle semble multifactorielle, sous l'influence de facteurs environnementaux et génétiques.

Les maladies inflammatoires chroniques intestinales (MICI) posent un problème de santé publique en raison de leur haute incidence chez l'adulte jeune et du cours évolutif chronique de la maladie. La mortalité n'est pas accrue mais la morbidité et l'altération de la qualité de vie ne sont pas négligeables.

L'étude épidémiologique de la MC revêt deux centres d'intérêt : en premier lieu, donner une idée de l'ampleur du problème de même que son impact social potentiel. En second lieu, mettre en évidence les facteurs génétiques et environnementaux impliqués dans la pathologie de la maladie. La MC a été décrite pour la première fois en 1932. Depuis, son incidence n'a cessé de s'accroître dans les pays développés et aussi actuellement, dans les pays en voie de développement.

L'étude épidémiologique de la MC pose de grosses difficultés [1]. Plusieurs aspects posent des problèmes majeurs. Les symptômes peuvent être insidieux dans la phase initiale et beaucoup de patients connaissent un retard de diagnostic, en particulier dans les pays en voie de développement où l'accès aux soins médicaux est limité $[1,2]$. Les définitions du tableau clinique ont considérablement varié : il en est de même pour la prise de conscience du diagnostic, du lieu de la prise en charge (hospitalier ou en ambulatoire) et les méthodologies [1, 2]. 
Le but de la présente revue est de réunir les données épidémiologiques disponibles dans les pays européens au cours des 3 dernières décennies en mettant l'accent sur l'épidémiologie descriptive.

\section{INCIDENCE ET PRÉVALENCE}

L'incidence de la MC en Europe varie de 0,3 à 9,8 cas pour $10^{5}$ personnes par an (Tableau I) $[1,2]$.

La prévalence varie de 8,3 à 214 cas pour $10^{5}$ personnes. Ces données sont fournies par plusieurs centres européens [2],

\section{Variations géographiques}

Un gradient nord-sud de l'incidence de la MC a été établi (Tableau I) ; l'incidence supérieure concerne le Royaume-Uni et la Scandinavie avec une incidence inférieure en Espagne et en Grèce [1-3, 19].

La population des MIC1 dans l'Union Européenne met en évidence une incidence de MC en Europe du nord et du sud respectivement de $7 / 10^{5}$ et $3,9 / 10^{5}$ [3].

En réalité, aucune étude de population n'a été entreprise avant les années 80 (Tableau I) et les études les plus récentes en Italie, en Grèce et en Espagne du nord [2, 3, 15] ont montré une incidence équivalente ou même supérieure à celles des pays de l'Europe du nord [3. 17]. Ceci reflète une meilleure mise en évidence des cas ou une émergence de la MC [16]. Par exemple, une très faible incidence de MC a été observée en Ionnie (Grèce) alors que l'incidence est 4 fois supérieure en Crète au cours de la même période $[15,16,19]$. Ceci pourrait être expliqué par le développement rapide du tourisme en Crète et l'occidentalisation du style de vie de nombreux crétois [16].

TABLEAU I. TAUX D'INCIDENCE POUR 100000 PERSONNES PAR AN

\begin{tabular}{|c|c|c|c|}
\hline Pays & Période étudiée & Incidence & Référence \\
\hline \multicolumn{4}{|l|}{ Europe du Nord } \\
\hline Norvège - Oslo & $91-93$ & 7,9 & 3 \\
\hline \multirow[t]{2}{*}{ Suède } & $65-83$ & 6,6 & 5 \\
\hline & $83-87$ & 6,7 & 4 \\
\hline Stockholm & $85-89$ & 4.9 & 6 \\
\hline Danemark & $91-93$ & 7.3 & 3 \\
\hline \multirow[t]{2}{*}{ Islande } & $80-89$ & 3,1 & 7 \\
\hline & $91-93$ & 7.8 & 3 \\
\hline Iles Faroe & $81-88$ & 3.6 & 8 \\
\hline Ecosse & $85-87$ & 9,8 & 9 \\
\hline Angleterre & $91-93$ & 3,8 & 3 \\
\hline Allemagne & $81-84$ & 4 & 10 \\
\hline Essen & $91-93$ & 4,4 & 3 \\
\hline Pays-Bas & $90-94$ & 6.9 & 11 \\
\hline France & $88-90$ & 3,2 & 12 \\
\hline Belgique - Bruxelles & $92-93$ & 4.1 & 13 \\
\hline Liège & $93-96$ & 4,8 & 14 \\
\hline \multicolumn{4}{|l|}{ Europe du Sud } \\
\hline Grèce - Crète & $90-94$ & 3,9 & 15 \\
\hline Est de la Grèce & $82-91$ & 0.3 & 16 \\
\hline Italie & $78-92$ & 2,8 & 17 \\
\hline Florence & $91-93$ & 3.3 & 3 \\
\hline Palerme & $91-93$ & 6,6 & 3 \\
\hline Espagne - Grenade & $79-89$ & 0,9 & 18 \\
\hline $\mathrm{N}-\mathrm{E}$ & $91-93$ & 5,2 & 3 \\
\hline Portugal - Braga & $91-93$ & 6.6 & 3 \\
\hline Almada & $91-93$ & 1,6 & 3 \\
\hline
\end{tabular}

Dans l'ensemble, il semble exister une prédominance des patients dans les zones urbaines [3], telles qu'en Suède où l'incidence de la $\mathrm{MC}$ a été trouvée supérieure dans 3 centres urbains par comparaison au monde rural [26] 
(Fig. 1).

La différence entre les populations de zone urbaine et rurale est également retrouvée en Europe du sud, par exemple à Héraklion : 4,3/10 et $1,6 / 10^{5}$ respectivement dans des régions urbaines et rurales [15].

Figure 1. Taux d'incidence annuelle de MC ajustés pour l'âge en zones rurales et urbaines en Suède [4],

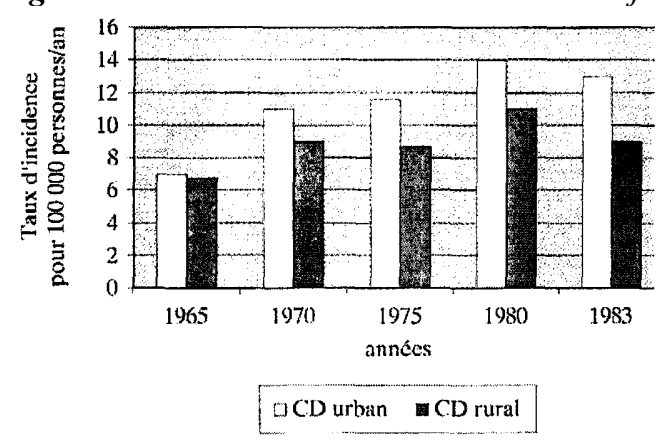

Figure 2. Evolution chronologique de l'incidence de la MC [2].

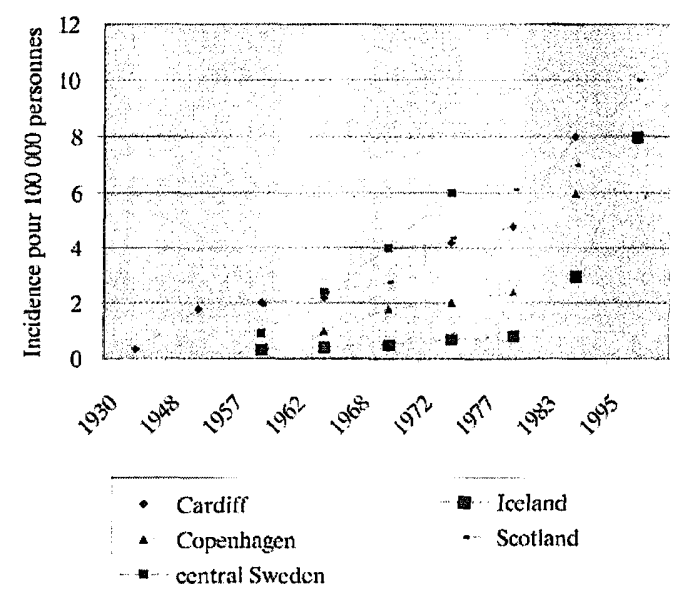

\section{Incidence au cours du temps}

Entre les années 50 et 80, on a assisté à un accroissement d'incidence de la MC en Europe du nord [20]; cet accroissement est représenté dans la figure 2.

En Suède, l'incidence annuelle moyenne était de 6,1/1 $\hat{u}^{5}$, avec des variations allant de $2 / 10^{5}$ en 1964 à $9,8 / 10^{5}$ en $1977[5]$.

A Stockholm, une étude au cours de la période 1955-1989 a montré une incidence moyenne accrue de $15 \%$ au cours d'une période de 5 ans; durant les deux dernières décennies de cette période d'étude, l'incidence est toutefois restée stable avec une valeur moyenne de $4,6 / 10^{5}$ [5].

En Ecosse, l'incidence annuelle moyenne au cours de la période 55-87 était de 5,4/10 5 avec des extrêmes de $1,3 / 10^{5}$ en 1955 et $9,8 / 10^{5}$ en 1985 [9].

En Islande, l'accroissement de l'incidence pour la décennie $80-89\left(5,6 / 10^{5}\right)$ était significativement supérieure à celle comparée pour la décennie précédente $70-79\left(0,9 / 10^{5}\right)$ [7].

A Copenhague, l'incidence s'est élevée de $1 / 10^{5}$ dans les années 60 à $4,1 / 10^{5}$ au cours de la dernière période 7987.

En somme, l'accroissement général d'incidence de la MC semble avoir cessé en Europe du nord depuis les 
années 1980 avec une exception pour l'Ecosse du nord ; mais il n'est pas clairement établi si l'étude écossaise, conduite sans appareillage pour l'âge reflète un accroissement réel : il serait intéressant d'observer une incidence élevée maintenue dans toutes les catégories d'âge [1, 19, 20].

Toutefois en Europe du sud, l'incidence paraît croître encore dans certaines régions. A Florence, un accroissement double a été observé au cours de la période d'étude 78-92 [17].

Une étude réalisée en Grèce (Héraklion), a montré une incidence annuelle de 1,9/10 en 1990 qui est montée à $3.8 / 10^{5}$ en $1994[15]$.

En Espagne, aucun accroissement de l'incidence n'a été démontré au cours de la période d'étude 1979-1988 [18].

\section{Rapport homme/femme}

Dans la plupart des études, on observe une légère prédominance féminine de la $\mathrm{MC}[1,19,21]$ mais plusieurs études ont démontré l'absence de différence entre les sexes [3,5]. La prédominance féminine a été fréquemment décrite dans de nombreuses régions avec des taux d'incidence faible comme en Grèce [16]. Au contraire, en Crète, la MC semble plus commune chez l'homme que chez la femme ; peut-être les Crétoises sont-elles moins exposées à certains facteurs de risque - tabagisme ou contraceptifs oraux - par rapport à d'autres femmes européennes [15].

\section{Age d'apparition}

Le diagnostic de MC est posé le plus fréquemment chez les patients au cours de la période de 20 ans, ce qui n'empêche pas que le diagnostic soit posé à tous les âges ; 1.0 à $15 \%$ des cas sont diagnostiqués avant le stade adulte [1].

Certaines études ont décrit une distribution bimodale avec un second pic d'incidence au cours des années 70-80 $[9,22]$. D'une façon habituelle, l'incidence annuelle diminue avec l'âge [3, 23] même si l'âge moyen du diagnostic a augmenté au cours du temps, ce qui résulte en partie d'un accroissement de la population âgée en Europe $[4,6,19,21]$.

Des observations d'enfants développant une MC ont été publiées à plusieurs reprises [24]. Récemment, la mise en évidence d'un accroissement d'incidence des MICI chez l'enfant a été constatée : à Stockholm, l'incidence de MC parmi les enfants a doublé, venant de 2,4 à 5.5/1000 000 entre les années 1990-92 et 1996-98 [19, 25].

\section{Retard de diagnostic}

Les symptômes de MC sont relativement insidieux au début et le diagnostic peut être difficile. Le retard de diagnostic a varié de façon significative. Par exemple dans l'étude islandaise, le temps moyen entre l'apparition des symptômes et le diagnostic est de 10,1 mois mais les extrêmes varient de 0,75 à 120 mois [7].

En Suède, le temps moyen écoulé avant l'apparition des symptômes et le diagnostic était de 5 mois avec des extrêmes de 0 à 599 mois [6].

En Hollande, la durée moyenne du temps écoulé avant l'apparition des symptômes et le diagnostic était de 6 mois et le pourcentage de patients qui présentaient des plaintes plus d'un an avant le diagnostic était de $31 \%$ [11].

\section{Localisation des lésions}

Quelques décennies auparavant, la MC était considérée comme une lésion essentiellement localisée à l'intestin grêle et en particulier à l'iléon terminal telle que Crohn et al. l'avaient décrite dans leur première publication [19].

Le tableau classique de MC iléocaecale était la localisation la plus commune ; les lésions du tractus gastroduodénal étaient rares [19].

Néanmoins, dans plusieurs études, une proportion croissante d'affection colorectale a été observée $[6,7,9,22]$.

L'introduction de la coloscopie a du moins en partie expliqué cet accroissement d'incidence des colites [2]. 
L'accroissement d'incidence des localisations gauches chez le sujet âgé a eu tendance à devenir plus fréquent [26-28], ce qui est une autre explication.

Toutefois, cette constatation n'était pas généralisée puisqu'une étude réalisée dans la région de Liège a montré que diverses localisations survenaient de façon identique chez le sujet jeune et le patient âgé [23]. Une modification des facteurs de l'environnement influençant diverses localisations, pourrait être en cause.

\section{Facteurs d'environnement}

Certains facteurs d'environnement ont été suggérés comme capables d'influencer le développement de la MC, tels que le tabagisme et la prise de contraceptifs oraux [29].

Le tabagisme semble être un facteur significatif de développement de MC, spécialement chez la femme [29, 32], excepté dans une étude israélienne ce qui suggère certaines variations de prédisposition génétique [30].

Les fumeurs seraient exposés à des formes plus sévères de la $\mathrm{MC}$ et l'affection récidiverait plus rapidement après chirurgie, ceci indépendamment de la localisation des lésions [29].

Dans une étude, l'exposition passive au tabagisme chez l'enfant pourrait augmenter le risque de développer une MC [31].

Le rôle des contraceptifs oraux n'est pas clair ; un lien possible entre contraceptif oral et MC a été également suggéré, bien que les données actuellement disponibles soient encore controversées [29]. Les contraceptifs oraux ont été mis en cause comme risque de récidive de la maladie [29].

Un agent viral a également été suggéré dans la MC ; plusieurs études ont suggéré qu'une exposition précoce à la rougeole était un facteur de risque $[33,34]$ mais une autre étude n'a pas confirmé cette observation [35].

Aucun lien évident n'a été établi entre l'administration d'un vaccin contre la rougeole dans l'enfance et le risque de développer une MC [36]. En outre, une chute de l'incidence de la MC dans la population jeune pourrait résulter d'un programme de vaccination [36].

\section{CONCLUSION}

En Europe, l'incidence de la MC a significativement augmenté au cours de la seconde moitié du XX $\mathrm{XX}^{\mathrm{e}}$ siècle. Elle paraît actuellement stable en Europe du nord mais elle continue à augmenter en Europe du sud.

L'apparition de la maladie chez le sujet jeune et chez le sujet âgé a augmenté bien qu'il existe actuellement un pic d'incidence au cours de la $3^{\mathrm{e}}$ décade. Une affection plus diffuse intéressant le tractus digestif supérieur et principalement l'ensemble du côlon semble également plus fréquente qu'auparavant.

Le tabagisme est clairement devenu le facteur environnemental prédominant associé à la survenue d'une maladie de Crohn.

\section{RÉFÉRENCES}

1. LOFTUS E., SANDBORN W. - Epidemiology of inflammatory bowel disease. Gastroenterol. Clin. N. Am., 2002,31. 1-20.

2. IRVINE E., FARROKHYAR F., SWARBRICK E. - A critical review of epidemiological studies in inflammatory bowel disease. Scand.

J. Gastroenterol., 2001, 1.2-15.

3. SHIVANANDA S., LENNARD-JONES J., LOGAN R.. FEAR N., PRICE A., CARPENTER L., VAN BLANKEN-STE1N M., and the EC-1BD study group. - Incidence of inflammatory bowel disease across Europe : is there a difference between North and South ? Gut, $1996,39,690-697$.

4. EKBOM A., HELMICK. C., ZACK M., AD AMI H. - The epidemiology of inflammatory bowel disease : a large population based study in Sweden. Gastroenterology, 1991.100, 350-358. 
5. L1NDBERG E., JARNEROT G. - The incidence of Crohn's disease is not decreasing in Sweden. Scand. J. Gastroenterol., 1991,26,495500 .

6. LAPIDUS A., BERNELL O., HELLERS G., PERSSON P., LOFBERG R. — Incidence of Crohn's disease in Stockholm county, 19551989. Gut. 1997. 41,480-486.

7. BJORNSSON S., JOHANNSSON H., ODDSSON E. — Inflammatory bowel disease in Iceland, 1980-1989. Scand. J. Gastroenterol, $1998.33,71-77$

8. ROIN F., ROIN J. — Inflammatory bowel disease in the Faroe Islands. 1981-1988. Scand. J. Gastroenterol., 1989,24,44-46.

9. KYLE J. - Crohn's disease in the North eastern and Northern Isles of Scotland : an epidemiological review. Gastroenterology, 1992, $103,392-399$.

10. DAISS W., SCHEUREN M., MALCHOW H. - Epidemiology of inflammatory bowel disease in the county of Tubingen. Scand. $J$. Gastroenterol.. 1989,24.39-43.

11. RUSSEL M., DORANT P., VOLOVICS P., BRUMMER R., POP P., MURIS J., BOS P., LIMON ARD C., STOCKBRUG-GER R., The South Limburg Study Group. - High incidence of inflammatory bowel disease in the Netherlands. Dis. Colon Rectum. 1998.41. 33-40.

12. GOWER ROUSSEAU C., SALOMEZ J., DUPAS J. — Incidence of inflammatory bowel disease in Northern France. Gut. 1.994, $35,1433-1438$

13. GOSSUM V., ALDER M., DE REUCK M., DEVIS G., FIASSE R., VANHEUVERZWlJN R. — Epidemiology of IBD in Brussel's area. Acta Gastroenterol. Belg., 1996,59,7-9.

14. LATOUR P., LOUIS E., BELAICHE J. - Incidence of inflammatory bowel disease in the area of Liege : a three years prospective study. Acta Gastroenterol. Belg., 1998,62,410-413.

15. MANOUSOS O.. KOUTROUBAKIS I., POTAMIANOS S., ROUSSOMOUSTAK.AKI M., GOURTSOYIANNIS N., VLACHONIKOLIS I. - A prospective epidemiologic study of Crohn's disease in Heraklion, Crete. Scand. J. Gastroenterol., 1996,31,599603.

16. VTSIANOS E., M AS ALAS C., DERKOUROPOULOS M., DALEKOS G., LOGAN R. - Incidence of inflammatory bowel disease in North West Greece : rarity of Crohn's disease in an area where ulcerative colitis is common. Gut, 1994,35, 369-372.

17. TRALlORI G., PALL1 D., SA1EVA C., BARDAZZI G., BONANOMI A.. d'ALBASIO G., GALLI M., VANNOZZ1 G., MILLA M., TARANTINO O.. RENAI F., MESSORI A., AMOROSI A.. PACINI F., MORETTINI A. - A population based study of inflammatory bowel disease in Florence over 15 years (1978-92). Scand. J. Gastroenterol., 1996,31,892-899.

18. MARTINEZ SALMERON J., RODRIGO M., de TERESA J., NOGUERAS F., GARCIA MONTERO M., de SOLA C, SALMERON J., CABALLERO M. - Epidemiology of inflammatory bowel disease in the province of Granada, Spain : a retrospective study from 1979 to 1988. Gut, 1993,34, 1207-1209.

19. LAPIDUS A. - The changing epidemiology of inflammatory bowel diseases. Acta Gastroenterol. Belg.,. vol. LXIV, 2001, 155-159.

20. LOGAN R. - Inflammatory bowel disease incidence up, down or unchanged ? Gut, 1998,42.309-311.

21. MUNKOLM P., LANGHOLZ E., HAAGEN NIELSSEN O., KREINER S., BINDER V. — Incidence and prevalence of Crohn's disease in the county of Copenhagen, 1962-1987 : a six fold increase in incidence. Scand. 1. Gastroenterol., 1992.27, 609-614.

22. RODE J., ROBERTS G., WILLIAMS G., MAYBERRY J., RHODES J. — Cardiff Crohn's disease jubilee : the incidence over 50 years. Gut, 1988,29.346-351.

23. PIRONT P., LOUIS E., LATOUR P., PLOMTEUX O., BELAICHE J. - Epidemiology of inflammatory bowel disease in the elderly in the province of Liege. Gastroenterol. Clin. Biol., 2002.26,157-161.

24. MAMULA P.. TELEGA G., MARKOW1TZ J., BROWN K., RUSSO P., PICCOLI D., BALASSANO R. - Inflammatory bowel disease in children 5 vears of age and younger. Am. J. Gastroenterol, 2002, 97. 2005-2010.

25. ASKLING J., GRAHNQUIST L.,EKBOM A., FINKEL Y. — Incidence of paediatric Crohn's disease in Stockholm, Sweden. Lancet, 1999,354. 1179.

26. PAGENAULT M., TRON I.. ALEXANDRE J, CRUCANT E, DABADIE A., CHAPERON J. — Incidence des maladies inflammatoires du tube digestif en Bretagne (1994-1995). Gastroenterol. Clin. Biol., 1997.21, 483-490.

27. SOFTLEY A., MYREN J., CRAMP S., BOUCHIER I., WASHINGTON G., DE DOMBAL F. — Inflammatory bowel disease in the elderlv patient. Seand. J. Gastroenterol., suppl., 1988,144.27-30. 
28. POLITO J., CHILDS B., MELLITS E., TOKAYER A., HARRIS M., BAYLESS T. — Crohn's disease : influence of age at diagnosis on site and clinical type of disease. Gastroenterology. 1996. 111. 580-586.

29. KRISHNAN A.. KORZENIK J. - Inflammatory bowel disease and environmental influences. Gastroenterol. Clin. N. Am.. 2002,31, 2139.

30. REIF S., KLEIN I.,ARBER N., GILAT T. — Lack of association between smoking and inflammatory bowel disease in Jewish patients in Israel. Gastroenterology. 1995. 108, 1683-1687.

31. PERSSON P.. AHLBOM A., HELLERS G. - Inflammatory bowel disease and tobacco smoke, a case-control sludy. Gut, $1990,31,1377-1381$.

32. BRIDGER S., LEE J., BJ ARNASON I., LENNARD JONES J.. MACPHERSON A. — In siblings with similar genetic susceptibility for inflammatory bowel disease, smokers tend to develop Crohn's disease and non-smokers develop ulcerative colitis. Gut, 2002,51,21-25.

33. MONTGOMERY S., MORRIS D., POUNDER R, WAKEFIELD A. - Paramyxovirus infections in childhood and subsequent inflammatory bowel disease. Gastroenterology, 1999. 116,796-803.

34. PARDI D., TREMAINE W., SANDBORN W.,LOFTUS E, POLAND G., HARMSEN W., ZINSMEISTER A., MELTON L. - Early measles virus infection is associated with the development of inflammatory bowel disease. Am. J. Gastroenterol., 2000.95, $1480-1485$.

35. IZUKA M., SAITO H., YUKAWA M., ITOU H., SHIRA-SAKA T., CHIBA M., FUKUSHIMA T., WATANABE S. - No evidence of persistent mumps virus infection in inflammatory bowel disease. Gat, 2001,48,637-641.

36. FEENEY M., CLEGG A.. WINWOOD P., SNOOK J., for the East Gastroenterology group. — A case control study of measles vaccination and inflammatory bowel disease. Lancet, 1997,350, 764-766.

\section{INTRODUCTION}

Crohn's disease (CD) is a chronic inflammatory disease which may affect any part of the gastrointestinal tract.

The etiology is still precisely unknown but seems to be multifactorial, with both environmental and genetic influence.

This Inflammatory Bowel Disease (1BD) is a health problem because of its high incidence in early adulthood and its, chronic clinical course. Mortality is not increased but morbidity and decreased quality of life are not negligible.

Epidemiologic study of CD has two main interests: first, to give an idea of the magnitude of the problem as well as its potential social impact; secondly to suggest genetic or environmental factors potentially involved in the pathogenesis of the disease.

CD has been first described in 1932. Since then its incidence has increased first in developed countries and currently also in developing countries.

Epidemiologic study of CD are fraught with difficulty [1]. Several features pose major problems. The symptoms may be insidious in onset and many patients may experience a delay in the diagnosis, particularly in developing countries with limited access to medical care $[1,2]$.

Case definitions have varied considerably; diagnostic awareness, case ascertainment (hospital or out patient) and methodology may vary as well $[1,2]$.

The aim of this review is to gather epidemiological data from European countries over the last three decades, focusing on descriptive epidemiology.

\section{INCIDENCE AND PREVALENCE}

The incidence of CD in Europe ranges from 0.3 to 9.8 cases per $10^{5}$ person-years (Table I) $[1,2]$. 
The prevalence ranged from 8.3 to 214 cases per $10^{5}$ persons. These data were available from several centres in Europe [2],

\section{Geographic variations}

A north-south gradient of CD incidence has been described (Table I) ; the higher incidence occur in UnitedKingdom and Scandinavia and the lower in Spain and Greece [1-3,19].

The EC-IBD population based study reported an incidence for CD in northern and southern Europe of $7 / 10^{5}$ and $3,9 / 10^{5}$ respectively [3].

In reality, no population based studies were conducted before the eighties (Table 1) and the more recent studies in Italy, Greece and Northern Spain $[2,3,15]$ have shown an incidence as great or greater than in some countries in Northern Europe [3,17], This could reflect better case ascertainment or the emergence of CD [16], For example, a very tow incidence of CD was found in Ionnina (Greece) although the incidence was fourfold in Crete at the same time $[15,16,19]$. This could be explained by the rapid development of tourism in Crete and the "Westernised" life style of many Cretans [16].

Overall it seemed to be a predominance of patients from urban areas [3], like in Sweden where incidence of CD was found to be higher in three urban counties compared to rural counties [26] (Fig 1).

TABLE I. INCIDENCE RATE PER 100000 PERSONS-YEAR

\begin{tabular}{|c|c|c|c|}
\hline Country & Study period & Incidence & Reference \\
\hline \multicolumn{4}{|l|}{ Northern Europe } \\
\hline Norway - Oslo & $91-93$ & 7.9 & 3 \\
\hline \multirow{2}{*}{ Sweden } & $65-83$ & 6.6 & 5 \\
\hline & $83-87$ & 6.7 & 4 \\
\hline Stockholm & $85-89$ & 4.9 & 6 \\
\hline Denmark & $91-93$ & 7.3 & 3 \\
\hline \multirow{2}{*}{ Iceland } & $80-89$ & 3.1 & 7 \\
\hline & $91-93$ & 7.8 & 3 \\
\hline Faroe Islands & $81-88$ & 3.6 & 8 \\
\hline Scotland & $85-87$ & 9.8 & 9 \\
\hline Britain & $91-93$ & 3.8 & 3 \\
\hline Germany & $81-84$ & 4 & 10 \\
\hline Essen & $91-93$ & 4.4 & 3 \\
\hline Netherlands & $90-94$ & 6.9 & 11 \\
\hline France & $88-90$ & 3.2 & 12 \\
\hline Belgium - Brussels & $92-93$ & 4.1 & 13 \\
\hline Liege & $93-96$ & 4.8 & 14 \\
\hline \multicolumn{4}{|l|}{ Southern Europe } \\
\hline Greece - Crete & $90-94$ & 3.9 & 15 \\
\hline West Greece & $82-91$ & 0.3 & 16 \\
\hline Italy & $78-92$ & 2.8 & 17 \\
\hline Florence & $91-93$ & 3.3 & 3 \\
\hline Palermo & $91-93$ & 6.6 & 3 \\
\hline Spain - Granada & $79-89$ & 0.9 & 18 \\
\hline $\mathrm{N}-\mathrm{E}$ & $91-93$ & 5.2 & 3 \\
\hline Portugal - Braga & $91-93$ & 6.6 & 3 \\
\hline Almada & $91-93$ & 1.6 & 3 \\
\hline
\end{tabular}

This difference between urban and rural population has also been found in Southern Europe like in Heraklion: $4.3 / 10^{5}$ and $1.6 / 10^{5}$ in urban and rural region respectively [15].

\section{Incidence over time}

From the $50 \mathrm{~s}$ to the $80 \mathrm{~s}$, there was an increase in the incidence of CD in Northern Europe [20]; this increase is shown in figure 2 . 
In Sweden, the mean annual incidence was $6.1 / 10^{5}$, with variations from $2 / 10^{5}$ in 1964 to $9.8 / 10^{5}$ in 1977 [5].

In Stockholm, a study in 1955-1989 showed a mean increase incidence per five years period of $15 \%$; during the last two decades of the study period, however the incidence remained stable at a mean of $4.6 / 10^{5}[6]$.

In Scotland, the mean annual incidence during the period 55-87 was 5.4/10 $0^{5}$ with extremes of $1.3 / 10^{5}$ in 1955 and $9.8 / 10^{5}$ in 1985 [9].

In Iceland, the increase in the incidence for the decade $80-89\left(5.6 / 10^{5}\right.$ was significant compared with the previous decade $70-79\left(0.9 / 10^{5}\right)[7]$.

In Copenhagen, the incidence has increased from $1 / 10^{5}$ in $60 \mathrm{~s}$ to $4.1 / 10^{5}$ in the latest period [21].

Figure 1. Age adjusted annual incidence rates for CD by urban or rural residence in Sweden [4].

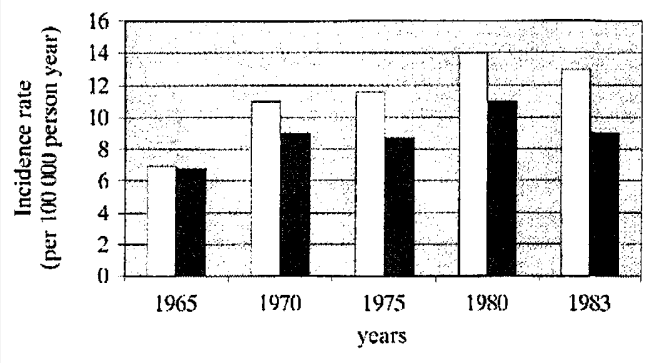

LCD urban aCD rural

Figure 2. Time trends in incidence of $C D$ [2].

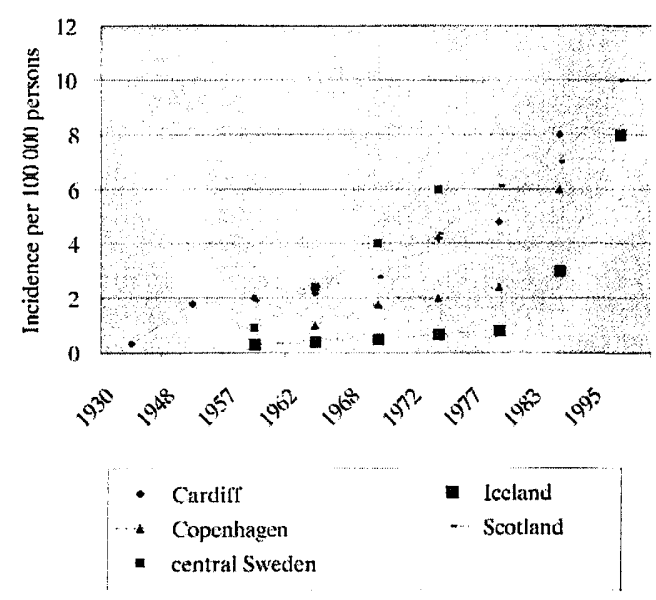

Overall, the general increase in incidence of CD seems to have ceased in Northern Europe from the 1980s with the exception of Northern Scotland; but it is unclear whether the Scottish study, which was not age standardised reflects a sustained increased : it would be interesting to see if high incidence was maintained in all ages [1-20].

In Southern Europe however, the incidence appears still increasing in some areas. In Florence a twofold increase was noted in the study period 78-92 [17].

A study in Greece (Heraklion) showed an annual incidence of $1.9 / 10^{5}$ in 1990 which increased to $3.8 / 10^{5}$ in 1994 $[15]$.

In Spain, no increasing incidence was shown over the study period 1979-1988 [18]. 


\section{Male - female ratio}

In most studies there was a slight female predominance in CD [1, 19, 21], but several studies have demonstrated no difference between genders $[3,5]$. The female predominance was often described in many regions with low incidence rates like Greece [16]. In contrast, in Crete, CD seemed commoner in males than females; perhaps Cretan women were less exposed to risks such as smoking or oral contraceptives than other European women [15].

\section{Age at onset}

The diagnosis of CD is made most frequently in patients in their 20s but can be made at any age; 10 to $15 \%$ of cases are diagnosed before adulthood [1].

Some studies have described a bimodal distribution with a second peak incidence in the 70s-80s [9, 22]. Commonly, the annual incidence declines with age $[3,23]$ even if the median age at diagnosis has increased over time, partly attributed to an increased proportion of elderly in European population [4, 6, 19, 21].

Reports of young children developing CD have been published several times [24]. Recently, evidence for increased incidence of IBD in children has appeared: in Stockholm, the incidence of CD among children have doubled from 2.4 to 5.5/100 000 between 1990-92 and 1996-98 [19, 25].

\section{Delay before diagnosis}

Symptoms of CD may be insidious at onset and diagnosis may be difficult.

Delay before diagnosis has significantly varied. For example, in an Iceland's study, the average time from the onset of symptoms to diagnosis was 10,1 months, but the extremes were 0.75 to 120 months [7].

In Sweden, the median time between onset of symptoms and diagnosis was 5 months with extremes of 0 to 599 months [6].

In Netherlands, median duration from onset of symptoms was 6 months and the percentage of patients with complaints for more than 1 year before diagnosis was $31 \%$ [11].

\section{Disease location}

Several decades ago, CD was considered to mainly affect the small bowel and particularly the terminal ileum as described by Crohn et al. in their original report [19].

Classical ileocaecal CD was the most common localisation; lesions in the gastroduodenal region were rare [19].

However in several studies, an increasing proportion of colorectal diseases has been found [6, 7, 9, 22].

The introduction of colonoscopy could partly explain the increase in incidence of colitis [2].

The increased incidence in elderly where left sided colitis tended to be more frequent [26-28], is another explanation.

However this was not generalised since in a study realised in the region of Liege, various disease locations occurred with a similar frequency in young and old patients [23]. A change in environmental factors influencing disease location could also be involved.

\section{Environmental factors}

Some environmental factors have been suggested as influences on the development of CD such as tobacco or use of oral contraceptives for example [29].

Cigarette use seems to be a significant risk factor for development of CD, especially in women [29, 32] except in an Israelian study, suggesting certain variations in genetic predisposition [30]. 
Smokers tend to have more severe disease and disease recurring more rapidly after surgery, independently of disease location [29].

In one study, exposure to passive smoking in childhood could increase the risk of developing CD [31].

Evidence is less clear for oral contraceptive; a possible link between oral contraceptive use and CD was also suggested, although it is still controversial data [29].

Oral contraceptives has been shown to be a risk of relapse of the disease [29].

A viral came has also been suggested for $\mathrm{CD}$; some studies have suggested that early exposure to measles virus is a risk [33. 34] but others have not confirmed this [35].

There is no clear evidence of a link between live attenuated measles vaccination in childhood and the risk of developing CD [36]. Therefore, a fall in the incidence of CD in young people should have been noted resulting from vaccination programme [36].

\section{CONCLUSION}

Incidence of CD in Europe has significantly increased over the second half of $20^{\text {th }}$ century. It now seems stable in Northern Europe but still increasing in Southern Europe.

Onset of the disease in young children and in the elderly has increased although there is still a peak incidence in the 20s. More diffuse disease affecting upper gastrointestinal tract and above all the colon are also more frequent than in the past.

Smoking has clearly emerged as a prominent environmental factor associated with the development of CD. 